\title{
Effect of Different Land Configuration, Superabsorbent and Nutrient Management on Yield and Economics of Soybean (Glycine max L.) -Safflower (Carthamus tinctorius) Cropping
} System

\begin{abstract}
Background: Oilseed crops are sources of fats and oils, which are essential for human diet, comprising about $40 \%$ of the calories in the diet of the average person safflower (Carthamus tinctorius) is a major rabi oilseed crop in the country. Like soybean its productivity is also very low as compared to the global average. Horizontal expansion to augment the food production is limited and the alternative way is to move on vertical growth by enhancing the productivity of the area. Therefore, production technology and management practices should be developed keeping in view all the above point, for efficient use of costly inputs, beside reduction in production cost, for instance residual effect of manures and fertilizers applied and nitrogen fixed by legumes can considerably bring down the production cost.

Methods: A field experiment was carried out to study the performance of soybean-safflower cropping sequence under different land configuration and nutrient management. Treatment consists of eighteen treatment combinations comprising three land configuration ( $L_{1}$ - flat beds, $L_{2}$ - ridges and furrow and $L_{3}$ - Broad bed furrow) and three superabsorbent levels $\left(S_{1}-0 \mathrm{~kg} \mathrm{ha}^{-1}, \mathrm{~S}_{2}-2.5 \mathrm{~kg} \mathrm{ha}^{-1}\right.$ and $\mathrm{S}_{3}-$ 5.0 kg ha-1) in main plot, two nutrient levels i.e., $\mathrm{N}_{1}-30: 60: 30$ NPK kg ha-1 $+5 \mathrm{t} \mathrm{FYM} \mathrm{ha-1}^{-1}$ and $\mathrm{N}_{2}-30: 60: 30: 30 \mathrm{NPKS} \mathrm{kg} \mathrm{ha-1}^{-1} 20 \mathrm{~kg}^{-3}$ $\mathrm{ZnSO}_{4}+5 \mathrm{t} \mathrm{FYM} \mathrm{ha}^{-1}$ to soybean and $\mathrm{N}_{1}-40: 20: 0 \mathrm{NPK} \mathrm{kg} \mathrm{ha-1}$ and $\mathrm{N}_{2}-30: 15: 0 \mathrm{NPK} \mathrm{kg} \mathrm{ha}^{-1}$ to safflower during kharif and rabi seasons, respectively as sub plot treatments were assigned in a split plot design with three replications.

Result: Broad bed furrows planting method with the application of 30:60:30:30 NPKS kg ha-1 $+20 \mathrm{~kg} \mathrm{ZnSO}_{4}+5 \mathrm{t} \mathrm{FYM} \mathrm{ha-1}^{-1}$ soybean and 40:20:0 NPK kg ha-1 to safflower during kharif and rabi seasons, respectively recorded significantly higher yield and yield attributes as well as net monetary returns but the applications of superabsorbent reordered non-significant effect during both the year of study.
\end{abstract}

Key words: Broad bed furrows, Economics, Growth, Yield and Yield attributes.

\section{INTRODUCTION}

Oilseed crops are sources of fats and oils, which are essential for human diet, comprising about $40 \%$ of the calories in the diet of the average person. India is amongst the largest producer and consumer of vegetable oils in the World. Oilseeds have been the backbone of agricultural economy of India since long. Indian vegetable oil economy is the fourth largest in the world next to USA, China and Brazil. Oilseed crops play the second important role in the Indian agricultural economy next to food grains in terms of area and production. India holds the first position in the world with an area of $26.4 \mathrm{~m}$ ha under oilseed cultivation, producing $30 \mathrm{~m}$ t (Economic Survey, 2016-2017). India's average oilseeds yield is $1135 \mathrm{~kg} \mathrm{ha}^{-1}$ which is very low as compared to world's average yield of $2000 \mathrm{~kg} \mathrm{ha}^{-1}$.

Among the edible oilseeds, soybean [Glycine max (L.) Merrill.] is the leading oilseed crop in the world with an area of $145 \mathrm{~m}$ ha. In India too, it is the most important oilseed crop with an area of $12 \mathrm{~m}$ ha and a production of $12.23 \mathrm{~m} \mathrm{t}$ with an average productivity of $1017 \mathrm{~kg} \mathrm{ha}^{-1}$ (http: Avww.sopa.org). Some of the major limiting factors for low productivity of soybean are limiting moisture conditions as this is mostly grown under rainfed conditions
Department of Agronomy, College of Agriculture, Vasantrao Naik Marathwada Krishi Vidyapeeth, Parbhani-431 401, Maharashtra, India.

Corresponding Author: C.K. Bhadre, All India Coordinated Research Project for Dryland Agriculture Vasantrao Naik Marathwada Krishi Vidyapeeth, Parbhani-431 401, Maharashtra, India. Email: ckbhadre@gmail.com

How to cite this article: Bhadre,C.K., Narkhede,W.N., Desai, M.M. (2022). Effect of Different Land Configuration, Superabsorbent and Nutrient Management on Yield and Economics of Soybean (Glycine max L.) -Safflower (Carthamus tinctorius) Cropping System. Legume Research. DOI: 10.18805/LR-4319.

Submitted: 10-01-2020 Accepted: 28-12-2021 Online: 03-03-2022

during kharif. The imbalanced and inadequate fertilization is also found to be one of the major limiting factors for its poor yield.

Likewise safflower [Carthamus tinctorius] is another very important oilseed crop grown world over. In India, it occupies about $5.9 \mathrm{~m}$ ha with a production of $6.8 \mathrm{~m} \mathrm{t}$ with an average productivity of $1145 \mathrm{~kg} \mathrm{ha}^{-1}$ (Economic Survey, 2012-2013). It is a major rabi oilseed crop in the country. Like soybean its productivity is also very low as compared to the global 
average. Safflower is also greatly affected by the poor nutrient management.

The population growth scenario predicts that by 2025 India will have 1.4 billion population requiring 301 million tonns of food. India may have to import $40 \mathrm{Mt}$ food grains by 2025 if the present growth rate of agriculture and population continues. This also seems to be an under estimate, as the present agricultural growth rate of 2.9 per cent cannot sustain by itself. Further, the demographic projections of India indicated that the per capita land availability from 0.14 ha in the year 2000 will be reduced to 0.10 ha by the year 2025. Moreover, besides the shrinking land area, the quality of land likely to remain available for agriculture will be poor due to severe competition from urbanization, industrialization and civic needs. Therefore, horizontal expansion to augment the food production is limited and the alternative way is to move on vertical growth by enhancing the productivity of the area. Hence, focusing the attention on sequential cropping, increasing the cropping intensity as well as production per unit area per unit time is now gaining ground for improved production (Kanwar and Sekhon, 1998). Food production must increase in order to cope with the expected population increase, while at the same time addressing pertinent global challenges such as environmental degradation and climate change. Overall, action is acutely necessary to resolve today's problems in order to prevent them from becoming tomorrow's catastrophes.

Soybean and safflower are grown as major kharif and rabi crops, respectively in the Marathwada region. Soybean based cropping system has attained, a great significance in terms of area, production and productivity, particularly in west-central region of India. Majority of the area covered under this cropping systems confined to rainfed farming situations belongs to Vertisols and associated soils (Bhatnagar and Joshi, 1999). These area normally receives an average annual rainfall of $800-1000 \mathrm{~mm}$, which is mostly erratic and undependable, causes excess or deficient moisture conditions during one or other stage of crop growth. Therefore, the yield of rainfed soybean is often low and erratic. The fluctuation in yield is mainly due to shortage and ill distribution of rainfall in kharif season and the low infiltration rate of soil.

In recent years, uncertainties in rainwater availability, the swings in the onset, continuity and withdrawal pattern of monsoon has made crop production more risky in rainfed areas (Singh, 2000). Under these circumstances, efficient rainwater management practices act as insurance for crops during abnormal rainfall situation. Drought stress is one of the major limiting factor that affect crop growth and productivity.

Forsustainable crop production system under rainfed condition, the conservation of rainwater and its efficient recycling are imperative. Among the various land configuration practices, flat bed, ridges and furrow and broad bed furrow systems are very promising in controlling surface runoff, reducing the soil loss through erosion and increasing infiltration. Land configuration plays an important role in conservation of maximum water in the soil. Chittaranjan (1981) stated that land configuration is the mechanical measure for better in situ moisture conservation as the soil profile acts as reservoir for moisture storage and this facility needs to be exploited to the maximum extent. Efficient management of soil moisture is important for agricultural production in the light of scarce water resources. Super absorbent polymers are used to reduce the impact of water stress during crop growth and development. These are made of hydrocarbon and can absorb and retain water several times of their weight. These absorbent contribute significantly to provide a reservoir of soil water to plants on demand in the upper layers of the soil where the root systems normally develop. The polymeric organic materials as super absorbent apart from improving the soil physical properties also serve as buffers against temporary drought stress and reduce the risk of plant failure during establishment. This is achieved by means of reduction of evaporation through restricted movement of water from the sub-surface to the surface layer. Drought stress is a key limiting factor leading to lower crop yields, especially in the late growing season of winter crops because there is not enough precipitation during the spring months.

Reddi and Reddi (1995) indicated that in many parts of the world, water is the major factor limiting crop production because water shortage affects several plant physiological processes (Sinaki et al., 2007).

Therefore, production technology and management practices should be developed keeping in view all the above point, for efficient use of costly inputs, beside reduction in production cost, for instance residual effect of manures and fertilizers applied and nitrogen fixed by legumes can considerably bring down the production cost. The present investigation entitled "Performance of soybean-safflower cropping sequence under different land configuration, and nutrient management." was taken up with the following objectives.

\section{MATERIALS AND METHODS}

The field experiment was conducted at Department of Agronomy, Vasantrao Naik Marathwada Krishi Vidyapeeth, Parbhani, during kharif and rabi season of 2016-17 and 2017-18. The soil of the experimental site was clayey in texture $(54.18 \%$ clay), alkaline in nature $(\mathrm{pH} 7.8)$, low in available nitrogen $\left(219.48 \mathrm{~kg} \mathrm{ha}^{-1}\right)$, medium in available phosphorus (17.32 $\mathrm{kg} \mathrm{ha}^{-1}$ ), fairly rich in available potassium (545.50 $\left.\mathrm{kg} \mathrm{ha}^{-1}\right)$ and medium in organic carbon $(0.54 \%)$. The topography of the experimental plot was fairly uniform and levelled. The experiment was comprised of a total of eighteen treatment combinations comprising three land configuration $\left(L_{1}-\right.$ flat beds, $L_{2}$ - ridges and furrow and $L_{3}$ Broad bed furrow) and three superabsorbent levels $\left(\mathrm{S}_{1}-0\right.$ $\mathrm{kg} \mathrm{ha}^{-1}, \mathrm{~S}_{2}-2.5 \mathrm{~kg} \mathrm{ha}^{-1}$ and $\mathrm{S}_{3}-5.0 \mathrm{~kg} \mathrm{ha}^{-1}$ ) in main plot, two nutrient levels i.e., $\mathrm{N}_{1}-30: 60: 30$ NPK kg ha-1 + 5 t FYM ha- $^{-1}$ 
and $\mathrm{N}_{2}-30: 60: 30: 30$ NPKS kg ha-1 $+20 \mathrm{~kg} \mathrm{Zn} \mathrm{SO}_{4}+5 \mathrm{t}$ FYM ha-1 to soybean and $\mathrm{N}_{1}-40: 20: 0$ NPK kg ha-1 and $\mathrm{N}_{2}-$ 30:15:0 NPK kg ha-1 to safflower during kharif and rabi seasons, respectively as sub plot treatments were assigned in a split plot design with three replication. During kharif and rabi season, full dose of NPK was applied as basal dose as per treatments to soybean and safflower. The soybean crop was sown at a spacing of $45 \times 5 \mathrm{~cm}$ on 25 June 2016 and harvested on 6 October 2016 during first year and during second year sown on 27 June 2017 and harvested on 13 October 2017 . The sowing of safflower was done as per land configuration at $45 \times 20$ cmon 15 November 2016 and 1 November 2017, during 2016-17 and 2017-18 and harvested on 23 March 2017 and 16 March 2018. Land configuration of BBF was formed with the help of BBF planter, ridges with the help of rider and flat bed was the our traditional sowing method on levelled field. Super absorbent polymers are useed for efficient management of soil moisture for agricultural production in the light of scarce water resources. Super absorbent polymers are also reduce the impact of water stress during crop growth and development. These are made of hydrocarbon and can absorb and retain water several times of their weight and it is applied @ $0,2.5$ and $5 \mathrm{~kg} \mathrm{ha}^{-1}$ along with the fertilizer aat the time of sowing. The various biometric observation were five randomly selected soybean and safflower plants from net plots, which were tied tags for their easy identification. The yield of soybean and safflower converted in to rupee/ha. During kharif and rabi season, fertilizer and superabsorbent applied at the time of sowing as per the treatments. The experiment crop of soybean received $1116.7 \mathrm{~mm}$ rains over 66 rainy days and $994.10 \mathrm{~mm}$ rains over 52 rainy days, respectively during first and second year of experiment. The three irrigations were provided to safflower, irrigation was applied equally to all plots of safflower irrespective to land configurations. The distribution of rainfall during first year was excess while it was deficit during second year. The wind velocity during the crop growth period ranged from 2.4 to $7.1 \mathrm{~km} \mathrm{hr}^{-1}$ during 2016-17 and 2.90 and $8.0 \mathrm{~km} \mathrm{hr}^{-1}$ during 2017-18.

\section{RESULTS AND DISCUSSION}

\section{Yield attributes and yield of soybean}

Yield attributing characters like number of pods/plant, weight of pods/plant and weight of seed/plant $(\mathrm{g})$ and seed yield of soybean showed remarkable improvement by adopting different land configuration method (Table 1). The broad bed furrows planting method wasmost efficient for increase in yield and yield attributing characters i.e. number of pods/ plant (28.25), weight of pods/plant $(9.85 \mathrm{~g})$ and weight of seed/plant (8.04) and seed yield (2202 $\left.\mathrm{kg} \mathrm{ha}^{1}\right)$ than flat bed planting but it was at par with the ridges and furrows (Table 1 and 2). This might be owing to better availability of the physical condition of the soil and soil moisture after completion of vegetative growth, which contributed for more photosynthesis and translocation of photosynthates towards reproductive organs i.e. from source to sink, which resulted in higher yield (Wadile et al., 2017). More favoured overall growth and yield attributing characters may be due to favourable seed bed, better aeration, scope for more space, light interception, benefit of more conserved moisture in furrows and its support at critical growth stages like flowering, pod initiation and development. This resulted in higher values of yield attributing characters and which in turn resulted in higher yields of soybean crop. This results correlate with the work of Jaypaul (1996), Jain et al. (2000) and Raut et al. (2000).

Applicationof superaosorbent exert non significant effect but the application of 30:60:30:30 NPKS $+20 \mathrm{~kg} \mathrm{ZnSO}_{4}+5$ t FYM ha-1 recorded significantly higher values of yield attributing characters i.e. number of pods/plant (26.56), weight of pods/plant $(8.71 \mathrm{~g})$ and weight of seed/plant (7.53) and seed yield $\left(2144 \mathrm{~kg} \mathrm{ha}^{-1}\right)$ than of the applicaton $30: 60: 30$

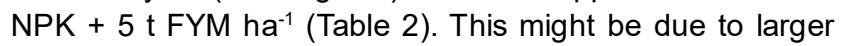
leaf area with this treatments. Larger leaf area resulted in more photosynthetic activities and more accumulation of carbohydrates which in turn increased dry matter accumulation. Similar results were also reported by Raut et al. (2003), Saxena et al. (2003) and More et al. (2006). Soybean has been reported to be responsive to sulphur with respect to dry matter accumulation (Shivakumar and Ahlawat, 2008; Prabhakaran and Lourduraj, 2003). The application of zinc significantly increased the dry matter accumulation at all the stages except at 30 DAS (Awlad et al., 2003; Thenua et al., 2014).

\section{Yield attributes and yield of safflower}

The practice of broad bed furrows $\left(L_{3}\right)$ in safflower showed great effect on the yield attributes of safflower during the investigation. Highest values of yield and yield attributes i.e. number of capitula/plant (25.01), weight of capitula/plant (48.81), weight of seed/plant (23.61) and seed yield (1933 $\mathrm{kgha}^{-1}$ ) was occurred with the broad bed furrows which was at par with the ridges and furrows and lowest values was recorded with the flat beds $\left(L_{1}\right)$. This might be due to broad bed furrows of sowing of safflower increases availability of soil moisture at peak period of growth. The similar findings were observed by Paliwal et al. (2011). Also may be due to more favoured overall growth and yield attributing characters due to favourable raised seed bed, better aeration, scope for more space, light interception, benefit of more conserved moisture in furrows and its support at critical growth stages like flowering, capitula initiation and development. This resulted in higher values of yield attributing characters and which in turn resulted in higher yields of safflower crop. The similar trend was observed in case of straw and biological yields as well as in harvest index also. These findings correlate with earlier findings of Mandal et al (2013) and Kadam (2015). Applicationof superaosorbent to safflower recorded non significant effect and the application of 40:20:00 NPK kg ha-1 to safflower had significant influence on yield (Table 2) and yield attributes of safflower than the 
Effect of Different Land Configuration, Superabsorbent and Nutrient Management on Yield and Economics of Soybean (Glycine...

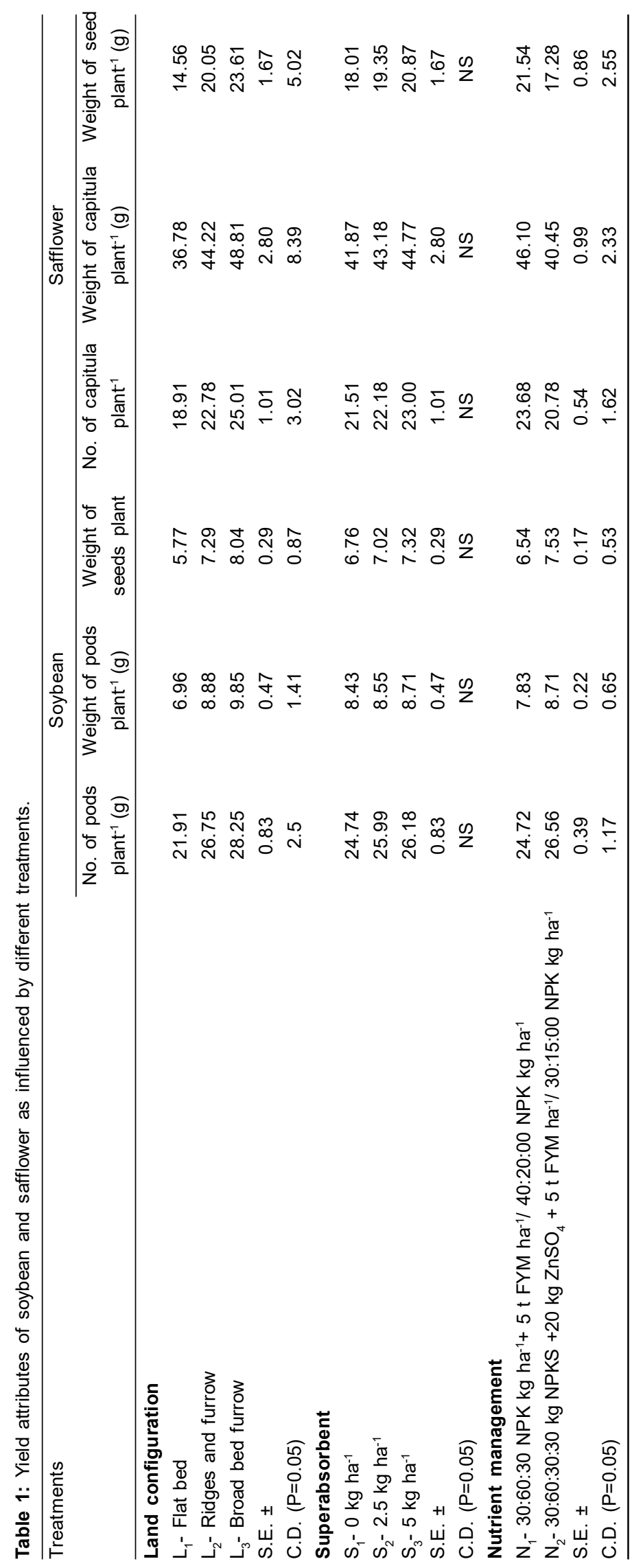




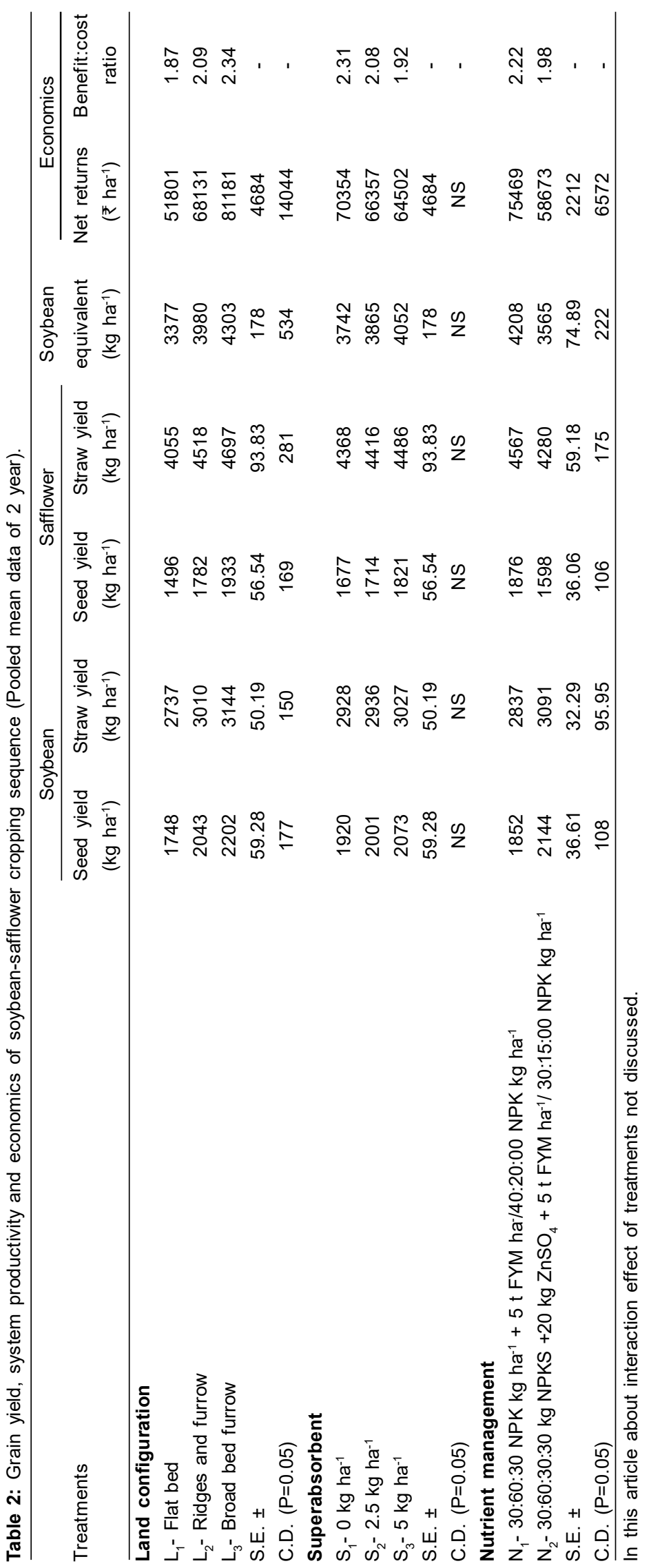


application of 30:15:00 NPK kg ha-1. Nitrogen and phosphorus are the two essential nutrients for safflower growth and development, therefore, optimization of their rates can strongly increase the seed yield in safflower. Application of nutrients has a vital role in early and vigorous plant growth especially under scarcity areas. Balanced application of fertilizers at the time of sowing led to higher plant growth. Proper application of nitrogen and phosphorus might have increased the chlorophyll content of the leaves and photosynthesis. $\mathrm{N}$ application was found to play a significant role in assimilation rate, stomatal conductance of water vapour (Dordas and Sioulas, 2008). The increase in the yield of safflower might be ascribed to cumulative effect of improvement in the growth as well as yield attributes and increased availability of the essential nutrients throughout the crop growth period. The results of present investigation are in lines with that of Girase et al. (1997) and Zohra Ahmed et al. (1985).

\section{System productivity}

The total productivity of the soybean-safflower cropping sequence expressed in terms of soybean equivalent yield indicated that it differed significantly due to differed land configuration and nutrient management to both the crops during both the years of investigation and in pooled results also (Table 2). The soybean equivalent yield of the cropping system was significantly higher with the practice of broad bed furrows than the flat beds practice and was at par with the ridges and furrows during both the years and in pooled results also. Similar results were also obtained by Singh et al. (1999), here total productivity of soybean-chickpea rotation in the BBF was greater than flat configuration. Applicationof different rates of superaosorbent resulted in non significant but in case of nutrient management, soybean equivalent yield was significantly increased with the application 30:60:30 NPK + 5 t FYM ha-1 $\left(\mathrm{N}_{1}\right)$ in kharif soybean followed by 40:20:00 NPK kg ha-1 $\left(N_{1}\right)$ to safflower in rabi season during both the years and in pooled results also (Table 2). The higher equivalent yield might be attributed to proper utilization of nutrients due to its sustained availability which resulted in better crop growth and ultimately higher grain yield. Similar findings were also reported by Tomar et al. (1996), Prajapat et al (2014) and Wanil et al. (2011).

\section{Economics}

Net monetary returns and $B: C$ ratio of cropping sequence were maximum in broad bed furrow planting method during both the years and in pooled mean than the flat beds and ridges and furrow. Also in the cropping sequence application 30:60:30 NPK + 5 t FYM ha-1 $\left(\mathrm{N}_{1}\right)$ in kharif soybean followed by 40:20:00 NPK kg ha-1 $\left(N_{1}\right)$ to safflower in rabi season obtained higher net monetary returns and benefit cost ratio during both the years of experimentation and in pooled results but the application of superabsorbent in the crooping sequence indicated non-significant effect (Table 2) Gautam et al. (2001) observed that net monetary return and benefit cost ratio increased with increasing level of fertilizer, highest net monetary return and benefit cost ratio recorded from highest level of fertilizer application $(80 \mathrm{~N}+40 \mathrm{P} \mathrm{kg} \mathrm{ha-1})$. These findings are in close conformity with those reported by Singh (2005), Arya et al. (2005), Pandey et al. (1999) and Auti et al. (1998).

\section{CONCLUSION}

For getting a sustainable crop production system under rainfed condition, the conservation of rainwater and its efficient recycling are imperative. Therefore use of broad bed furrows planting method along with the application 30:60:30:30 NPKS + 5 t FYM ha-1 $\left(\mathrm{N}_{1}\right)$ in kharif soybean followed by $40: 20: 00 \mathrm{NPK} \mathrm{kg} \mathrm{ha}{ }^{-1}\left(N_{1}\right)$ to safflower in rabi season found optimum for achieving maximum yield, yield attributes and monetary benefits in soybean-safflower cropping sequence (Table 1 and 2).

\section{Conflict of interest: None.}

\section{REFERENCES}

Arya, R.L., Kumar, L., Singh, K.K. and Kushwaha, B.L. (2005). Effect of fertilizers and tillage management in rice (Oryza sativa) chickpea (Cicer arietinum) cropping system under varying irrigation schedules. Indian J. Agron. 50(4): 256-259.

Auti, A.K.,S.C.Wadile and V.S., Pawar. (1998). Influence of levels and sources of fertilizer on yield of wheat. Journal of Maharashtra Aagricultural University. 23(1): 16-18.

Awlad, H.M., Chowdhury, M.A.H. and Talukder, N.M. (2003). Effect of sulphur and zinc on nodulation, dry matter yield and nutrient content of soybean. Pakistan Journal of Biological Sciences. 6(5): 461-466.

Bhatnagar, P.S. and Joshi, O.P. (1999). Soybean in Cropping System. In: Integrated Crop Management Series. FAO, Rome 3: 1-39.

Chitaranjan, S. (1981). Rainwater harvesting and recycling. Indian Journal of Soil Conservation,3: 119-143.

Dordas, C.A. and Sioulas, C. (2008). Safflower yield, chlorophyll content, photosynthesis and water use efficiency response to nitrogen fertilization under rainfed conditions. Indus. Crops and Products. 27(1): 75-85.

Gautum,V.S., Kushwaha, B.B., Nayak, S. and Kushwaha, S.S. (2001). Integrated nutrient management on kharif sorghum. Indian J. Dryland Agric. Res and Dev.16(1): 83-85.

Girase, P.D., Kamble, L.B. and Deolankar, A.B. (1997). Response of safflower to application of fertilizer under rainfed condition. Journal of Maharashtra Agricultural Universities.1: 148-149.

Jain, H.C., Deshmukh, M.R., Goswami, V. and Hedge, D.M. (2000). Studies on land configuration and seed hardening on productivity of sesame in different soil types. J. Maharashtra Agric. Univ. 25(1): 1-24.

Jayapaul, P., Uthayankumar, B., Markendevasagayami, M.B., Padian, J., Palchamy, A. and Balakrishnan, A. (1996). Effect of land configuratiuon methods, irrigation regimes and soil moisture conservation amendmentson soybean yield and quality charaecters. Crop Research.11(3): 253-257. 
Effect of Different Land Configuration, Superabsorbent and Nutrient Management on Yield and Economics of Soybean (Glycine...

Kadam, A.K. (2015). Effect of various land layouts and nutrient levels on growth, yield and quality of soybean [Glycine max (L.) Merrill.] under rainfed condition. M.Sc.(Agri.) Thesis, VNMKV, Parbhani (M.S.), India.

Kanwar, J.S. and Sekhon, G.S. (1998). Nutrient management for sustainable intensive agriculture. Ferttilizer News. 43(2): 33-40.

Mandal, K.G., Hati, K.M., Mishra, A.K. Bandyopadhyay, K.K. and Tripathi, A.K. (2013). Land surface modification and crop diversification for enhancing productivity of a vertisol. International Journal of Plant Propduction. 7(3): 455-472.

More, S.R., S.N. Mendhe and H.S. Kolte. (2006). Growth and yield attributes of soybean as influenced by nutrient management. Journal of Soil and Crops.18(1): 154-157.

Paliwal, D.K., Kushwaha, H.S. and Thakur, H.S. (2011). Performance of soybean (Glycine max) - wheat (Triticum aestivum) cropping system under land configuration, mulching and nutrient management. Indian Journal of Agronomy. 56(4): 334-339.

Pandey, I.B., Thakur, S.S., and Singh, S.K. (1999). Response of timely sown wheat (Triticumaestivum) varieties to seed rate and fertility level. Indian J. Agron. 44(4): 745-749.

Prabhakaran, N.K. and Lourduraj, A.C. (2003). Nutrient management in soybean. Agric. Res. 24(3): 230-228.

Prajapat, K., Vyas, A.K. and Dhar, S. (2014). Productivity, profitability and land-use efficiency of soybean based cropping system under different nutrient management practices. Indian Journal of Agronomy. 59(2): 229-234.

Raut, S.S., Basole, V.D., Deotale, R.D., IImulwar S.R. and Kadwe, S.B. (2003). Effect of hormone and nutrients on morpho-physiological characters and yield of soybean. Journal of Soils and Crops. 13: 135-139.

Raut, V.M., Taware, S.P., Halvankar, G.B. and Varghese, P. (2000). Comparison of different sowing methods in soybean. Journal Maharashtra Agriculturale Universitiesy. 25(2): 218- 219

Reddi, G.H.S. and Reddi, T.Y. (1995). Irrigation of Principal Crops. In: Efficient Use of lirrigation Water, $2^{\text {nd }}$ ed. Kalyani Publishers, New Delhi, India. pp. 229-259.
Saxena, S.C., Manral, H.C. and Chandel, A.S. (2003). Effect of organic and inorganic sources of nutrients on soybean. Indian J. Agron. 46(1): 135-140.

Shivakumar, B.G. and Ahlawar, I.P.S. (2008). Integrated nutrient management in soybean (Glycine max)-wheat (Triticum aestivum) cropping system. Indian Journal of Agronomy. 54(4): 273-278.

Sinaki, J.M., Heravan, E.M., Rad, A.H.S., Noormohammadi, G and Zarei, G. (2007). The effect of water deficit during growth stages of canola (Brassica napus L.). American-Eurasian Journal of Agricultural and Environmental Sciences. 2(4): 417-422.

Singh S., Kaul, J.N. and Kaur, N. (2005). Productivity of summer planted groundnut in relation to land configurations and the seeding rates. Environment and Ecology. 23(2): 246249.

Singh, D.P. (2000). Drought management in field crops. Recent Aadvances in Agronomy. pp. 253-277.

Singh, P., Alagarswamy, G., Pathak, P., Wani, S.P., Hoogenboom, G. and Virmani, S.M. (1999b). Soybean-chickpea rotation on Vertic Inceptisols I. Effect of soil depth and landform on light interception, water balance and crop yields. Field Crops Res. 63(3): 211-224.

Tomar, R.K., Namdeo, S.K.N. and Raghu, J.S. (1996). Productivity and economics of double cropping with pulses and oilseeds against the base crop wheat (Triticum aestivum) Indian J. Agron. 41(2): 205-208

Wadile, S.C., Solunke, A.V., Tumbhare, A.D. and Ilhe, S.S. (2017). Influence of land configurtation and nutrient management on yield, quality and economics of soybean (Glycine max)sweet corn (Zea mays) cropping sequence. Indian Journal of Agronomy. 62(2): 141-146.

Wani, A.G., Patil, V.S. and Todmal, S.M. (2011). Efficient alternative cropping systems. Project Directorate for Farming Systems Research, Modipuram, Meerut, India. pp. 339.

Zohra Ahmed, S., Medekkar and Shaik Mohamad. 1985. Response of safflower to nitrogen and phosphorus. Indian Journal of Agronomy. 30: 128-130. 